PAEDAGogia CHRISTIANA

$1 / 25$ (2010) - ISSN 1505-6872

Dariusz Stępkowski*

Warszawa

\title{
Friedricha Schleiermachera myślenie o wychowaniu jako dialogu pokoleń
}

Początki myślenia dialogicznego sięgają starożytnej Grecji, kiedy to tacy wielcy myśliciele, jak Sokrates i Platon, włączyli na pozór zwykłą rozmowę (gr. dia-logos) do kanonu metod dochodzenia do prawdy. Do tak powstałego paradygmatu filozofowania w czasach nowożytnych nawiązał niemiecki teolog, filozof i pedagog Friedrich Daniel Ernst Schleiermacher (1768-1834). Dialogiczny charakter jego myślenia nie wyraża się już jednak w pisaniu prac w konwencji dialogów, rozmów na zadany temat pomiędzy rzeczywistymi czy wymyślonymi bohaterami. Termin «dialog» odnosi się u niego raczej do samego myślenia i jego struktury. Patrząc od wewnątrz, tworzy je oscylacja między językiem a myśla, od zewnątrz natomiast - ruch poznawczy polegający na przechodzeniu od „transcendentnej podstawy” do wiedzy podmiotowej.

Schleiermacher w wielu (jeżeli nie wszystkich) swoich pracach posługiwał się powyższą konstrukcją. Odnosi się ona również do jego głównego dzieła pedagogicznego - Zarys sztuki wychowania (Grundzüge der Erziehungskunst), które w Polsce jest mało znane. W kontekście tego właśnie opracowania wyjaśniam najważniejszą myśl pedagogiki Schleiermachera, którą wyraził za pomocą słynnego pytania: „Czego właściwie chce pokolenie dorosłych od młodej generacji?".

Moje rozważania przedstawiam w czterech punktach. Najpierw szkicuję niedocenianą do tej pory w dorobku Schleiermachera teorię języka. Na jej tle w drugim punkcie wyjaśniam znaczenie specyficznego terminu «dywinacja» i wynikające z niego uzasadnienie dla czynności kształcenia. Następnie przechodzę do etycznej koncepcji Schleiermachera, którą odczytuję jako

* Ks. dr Dariusz Stępkowski SDB, adiunkt na Wydziale Nauk Pedagogicznych Uniwersytetu Kardynała Stefana Wyszyńskiego w Warszawie. 
przestrzeń stawania się podmiotu w wymiarze indywidualnym i wspólnotowym. Na zakończenie, w czwartym punkcie, koncentruję swoją uwagę na Zarysach sztuki wychowania i zawartego w nich novum - pytania o intergeneracyjność pedagogiki. Mam nadzieję, że w związku z obserwowanym renesansem pedagogiki międzypokoleniowej moja prezentacja przyczyni się nie tylko do popularyzacji koncepcji Schleiermachera w naszym kraju, lecz także do wyjaśnienia problemów powstających na skutek relacji międzypokoleniowych oraz wskaże sposób ich rozwiązywania przez dialog ${ }^{1}$.

\section{Język jako podstawa teorii wychowania}

Zdaniem współczesnego niemieckiego badacza Friedhelma Brüggena w recepcji pedagogiki Schleiermachera do tej pory nie poświęcono wystarczająco uwagi teorii języka. To właśnie w niej jednak ,,manifestuje się najdobitniej odwrót od transcendentalnego Ja Kanta i Fichtego ku intersubiektywności «transcendentnego My»" ${ }^{2}$. Być może na to dziwne przeoczenie miała wpływ opinia Hansa-Georga Gadamera, który zarzucał protestanckiemu teologowi i pedagogowi brak jasności w sprawie języka i pomijanie problemu ,języka jako języka”3, czyli odniesienia języka do sfery pozajęzykowej ${ }^{4}$.

Tej - jak postaram się wykazać - niesprawiedliwej ocenie sprzeciwiają się zarówno historycy idei ${ }^{5}$, jak i wspomniany już Brüggen. Jego zdaniem,

${ }^{1}$ W ostatnim czasie Marian Nowak przypomniał intergeneracyjne ujęcie pedagogiki. Niestety pominął przy tym zupełnie wkład Schleiermachera. Por. M. Nowak, Pedagogika wzorów i pedagogika spotkania w dialogu pokoleń, w: K. Franczak (red.), Dialog pokoleń, Warszawa 2007, s. 76-98.

${ }^{2}$ F. Brüggen, Freiheit und Intersubjektivität. Ethische Pädagogik bei Kant und Schleiermacher, mps, Münster 1986, s. 96. Jak do tej pory opracowanie Brüggena nie zostało wydane drukiem. Jest jednak dla mnie źródłem wielu inspiracji, co wykorzystałem w tym artykule.

${ }^{3}$ H.-G. Gadamer, Das Problem der Sprache in Schleiermachers Hermeneutik, w: tenże, Kleine Schriften, t. 3: Ideen und Sprache, Tübingen 1972, s. 140.

${ }^{4}$ Według Macieja Potępy, polskiego znawcy hermeneutyki i dialektyki Schleiermachera, błędną interpretację poglądów „dziewiętnastowiecznego Ojca Kościoła” spowodowało u Gadamera założenie psychologicznej wykładni rozumienia. Zgodnie z nią: „W życiowej naoczności procesu twórczego, w którym powstaje dzieło literackie, rozpoznał on [tj. Schleiermacher] warunek do poznania innego procesu, który za pomocą znaków pisma rozumie całość dzieła i z tego wyprowadza zamiar i właściwą duchowość dzieła" (M. Potępa, Dialektyka i hermeneutyka w filozofii Friedricha Daniela Schleiermachera, Łódź 1992, s. 143). Z tego właśnie powodu Gadamer wyeksponował przepaść między hermeneutyką Schleiermachera a swoją własna, proweniencji fenomenologiczno-egzystencjalnej (por. H.-G. Gadamer, Prawda i metoda. Zarys hermeneutyki filozoficznej, Warszawa 2004, s. 249-280).

${ }^{5}$ Por. M. Potępa, dz. cyt., s. 125-136; M. Frank, Einleitung des Herausgebers, w: F. Schleiermacher, Dialektik, t. 1, Frankfurt a. M. 2001, s. 34-91. 
u Schleiermachera ,językowość (Sprachlichkeit) przedmiotu pedagogiki jest konstytutywna dla [jej] statusu [jako] techniki"“. Pozostawiając na później wyjaśnienie specyficznej nomenklatury, której używa Schleiermacher w odniesieniu do wychowania (=sztuka) i pedagogiki (=technika), z naciskiem należy podkreślić, że, jego zdaniem, w języku dokonuje się podwójne zapośredniczenie: po pierwsze, między działaniem pedagogicznym a indywidualnością, którą oznacza on terminem Eigentümlichkeit, to znaczy „osobność” - ze względu na posiadane przez nią odrębne i niepowtarzalne własności, po drugie zaś między podmiotem zbiorowym (My) a napięciem czy nawet konfliktem, do jakiego dochodzi między dorosłymi a dorastającymi (będzie o tym mowa w ostatnim punkcie). Aby wyjaśnić te kwestie, trzeba zrekonstruować - co najmniej pobieżnie - Schleiermacherowską filozofię języka.

Krytyka filozofii transcendentalnej uświadomiła Schleiermacherowi, że istnieje ślepa uliczka myślenia nad podmiotowością, w którą wprowadza idealistyczne założenie absolutnego „«posiadania siebie samego» (podkr. F. S.)" "7. W swojej monografii Potępa wielokrotnie stwierdza, że: „Schleiermacher był pierwszym filozofem, który wyciagnął ważne [...] wnioski z załamania się «refleksyjnego modelu podmiotu»" ". Niewątpliwie jednym z nich było - jeśli można tak powiedzieć - odkrycie języka i jego roli w kształtowaniu rzeczywistości międzypodmiotowej. W przeciwieństwie do współczesnych nam strukturalistów Schleiermacher nie traktuje języka jako rzeczywistości samej w sobie, lecz jako medium, za pomocą którego udaje mu się uniknąć dwóch zagrożeń: z jednej strony solipsystycznego zamknięcia w pozornym dialogu między Fichteańskim Ja a Nie-Ja, z drugiej natomiast rezygnacji z aspiracji do obiektywnej, to znaczy pozapodmiotowej prawdy.

Początki Schleiermacherowskiej koncepcji języka sięgają słynnego traktatu pt. Mowy o religii do wykształconych spośród tych, którzy niq gardza (Über Religion. Reden an die Gebildeten unter ihren Verächtern). Jak trafnie zauważa Brüggen, młody wówczas teolog i myśliciel zastosował w nich „dialektykę mówienia religijnego". Epitet «religijny» nie charakteryzuje w tym przypadku właściwości przedmiotu, o którym jest mowa, lecz podkreśla to, że musi istnieć konieczny warunek każdej wypowiedzi, a mianowicie - odniesienie do „transcendentnej podstawy” (transzendenter Grund). Mówienie spełniające ten wymóg jest nie tylko religijne (od łac. re-ligare - 'związać na

\footnotetext{
${ }^{6}$ F. Brüggen, Freiheit, s. 156.

${ }^{7}$ F. Schleiermacher, Dialektik (1822), oprac. M. Frank, w: tenże, Dialektik, t. 2, Frankfurt a. M. 2001, s. 288.

${ }^{8}$ M. Potępa, dz. cyt., s. 11; zob. także: s. 91, s. 119, s. 121, s. 168.

${ }^{9}$ F. Brüggen, Freiheit, s. 93.
} 
nowo', 'powiązać raz jeszcze' ${ }^{10}$ ), lecz także dialektyczne. Aby to rozwinąć, należy przeprowadzić dalszą analizę.

Przy wyjaśnianiu terminu «dialektyka» Schleiermacher odwołuje się do Platona i etymologicznego sensu greckiego czasownika $\delta \imath \alpha \lambda \dot{\gamma} \gamma \varepsilon \sigma \theta \alpha \imath$ (dialegesthai $)^{11}$. Następnie stwierdza, że dialektyka jest „„«sztuką prowadzenia rozmowy» (podkr. F. S.)"12. Można mieć jednak watpliwość, czy autorowi chodzi o umiejętność przekonywania innych do własnych racji, czy też o sposób dochodzenia do prawdy. Tę pozorną niejednoznaczność rozstrzyga stwierdzenie Schleiermachera, że prowadzenie rozmowy, jest ugruntowane wyłącznie na prawdzie"'13.

Chociaż dialegesthai wskazuje w pierwszym rzędzie na dialog między różnymi podmiotami, to jednak nie wyklucza sytuacji, gdy podmiot ,prowadzi rozmowę z samym sobą" 14 . Ważniejsze jest to, aby dokonywało się „ciągłe wewnętrzne mówienie lub rozwijanie myśli”"15. Wynika to stąd, że, według Schleiermachera: „Mówienie i myślenie znajdują się w ścisłej zależności”'16. Nie chroni to jednak rozmowy przed jałowością. Wręcz przeciwnie - każda forma dialogu może zamienić się w pustosłowie, jeżeli nie będzie odnosiła się do przedmiotu rozmowy. Mówienie o czymś i myślenie o tym są dwiema czynnościami zachodzącymi równocześnie w obu podmiotach działających. To warunkuje prawdziwą rozmowę, to znaczy kreowanie i wymianę myśli $1^{17}$.

Ze względu na przedstawione dwa aspekty języka: myślenie i mówienie, należy zauważyć, że, według Schleiermachera, język jest nie tylko zwornikiem między nimi, lecz także otwiera drogę do „lepszego poznania i czystej

${ }^{10}$ Zob. P. Henrici, Od Cycerona do Schleiermachera: odmiany pojęcia ,,religia”, „Communio" 3 (2008), s. 31-40.

${ }^{11}$ Por. F. Schleiermacher, Dialektik, s. 47.

12 Tamże.

${ }^{13}$ Tamże, s. 48; zob. także: M. Frank, dz. cyt., s. 26-34.

${ }^{14}$ F. Schleiermacher, Dialektik, s. 5.

${ }^{15}$ Tamże.

16 Tamże, s. 127.

${ }^{17}$ Inaczej jest w hermeneutyce Gadamera. Język (jako metoda) zawiera w sobie już prawdę w postaci dziejów efektywnych (por. H.-G. Gadamer, Prawda, s. 493-515). A zatem wbrew rozróżnieniu zawartemu w tytule głównego dzieła - Prawda i metoda - nie pełni on funkcji mediacyjnej między tymi dwoma obszarami, lecz gwarantuje skuteczność wyprowadzania prawdy $\mathrm{z}$ metody. W związku z ukazującą się na tym tle kwestią podmiotu, Potępa stwierdza: „Schleiermacher unika scylli hermeneutycznej filozofii Heideggera i Gadamera, w której indywidualny podmiot zostaje zredukowany i rozmyty w takich pojęciach jak: «bycie przytomne» (Dasein), «język bycia» (Sprache des Seins), «historia oddziaływań» (Wirkungsgechichte), «tradycja» (Tradition) - z drugiej zaś charybdy koncepcji neostrukturalistycznych, które w ogóle uznają w filozofii za zbyteczne posługiwanie się pojęciem podmiotu" (M. Potępa, dz. cyt., s. 24). 
wiedzy"18. Jest to ważna cecha myślenia hermeneutycznego u tego autora, która odróżnia je od współcześnie dominującego modelu Gadamerowskiego. Według Potępy, „dla Gadamera «punktem archimedesowym», absolutną podstawą wiedzy o świecie [...] jest [...] nasze uczestnictwo w życiu ujętym jako nieskończony proces stawania się sensu"19. W takim ujęciu jednak „rolę «transcendentnej podstawy», określającej samoświadomość człowieka, przyjmuje [...] tradycja (dokładniej: dziejowa świadomość wzajemnych oddziaływań)"20.

Zanim w następnej części prześledzę, jak, według Schleiermachera, przebiega dialektyczny proces poznania, omówię nieco dokładniej koncepcję dwoistości języka. Kilkakrotnie już wspominany Brüggen przypisuje mu posiadanie „formy dialogicznej” ${ }^{21}$, która oznacza, że język ,jest jako środek [...] zarazem celem"22. W tej podwójnej funkcji widoczna jest, jego zdaniem, ,genetyczna struktura kształcenia"23, w której działanie pedagogiczne jest równocześnie methodos i telos. Zilustruję to, odwołując się do lingwistycznej koncepcji Wilhelma von Humboldta, pod którego wpływem nasz autor niewatpliwie się znajdował.

W Zarysie ogólnego typu języka (Grundzüge des allgemeinen Sprachtypus) wybitny dziewiętnastowieczny językoznawca mówi o ,zdolności do języka"24. Składają się na nią dwa przenikające się czynniki: z jednej strony każdemu człowiekowi dana jest a priori możliwość wytwarzania języka, która realizuje się - tak samo jak w ujęciu Schleiermachera - przez myślenie $\mathrm{i}$ w nim ${ }^{25}$, z drugiej natomiast strony język jest wytworem (produktem) tych czynności. W pierwszym przypadku chodzi o język w znaczeniu parole, czyli użycia wyrażającego się w indywidualnej mowie (Rede), w drugim zaś eksponowany jest on jako langue, a więc ukształtowany przez rozwój kultury zbiór ogólnych norm semantyczno-semiotycznych i zasad ich zasto-

${ }^{18}$ F. Schleiermacher, Dialektik, s. 54.

${ }^{19}$ M. Potępa, dz. cyt., s. 122 i nast.

${ }^{20}$ Tamże, s. 123.

${ }^{21}$ F. Brüggen, Freiheit, s. 107.

${ }^{22}$ Tamże.

${ }^{23}$ Tamże, s. 108.

${ }^{24}$ W. Humboldt, Zarys ogólnego typu języka, w: tenże, O myśli i mowie, Warszawa 2002, s. 403.

${ }^{25}$ Schleiermacher używa często wyrażenia sprechendes Denken, dosłownie znaczy ono „mówiące myślenie”. Potępa wyjaśnia ten zwrot w następujący sposób: „Język nie dochodzi zewnętrznie do myślenia, ponieważ myśl konstytuuje się dopiero w słowie. [Z drugiej strony m]yślenie nie jest czymś danym bez pośrednictwa języka, lecz dopiero w słowie uzyskuje ono swoją własną określoność, dzięki językowej formie. «Myślenie nie jest możliwe bez mowy, a ta ze swojej istoty jest warunkiem dokonania się myślenia» (podkr. D.S.)". M. Potępa, dz. cyt., s. 126. 
sowania. Nieuniknione przenikanie się obu tych postaci języka Humboldt wyjaśnia następująco: ,Język należy do mnie, ponieważ go wytwarzam. Nie należy do mnie, ponieważ nie mogę go wytwarzać inaczej, niż to robię, a że przyczyna tego leży we wszystkim, co mówią i powiedziały wszystkie pokolenia, o ile komunikacja językowa następowała u nich nieprzerwanie, zatem to od samego języka doznaję tego ograniczenia" ${ }^{26}$. Do zasygnalizowanej płaszczyzny międzypodmiotowej powrócę nieco dalej. W tej chwili chciałbym zwrócić uwagę na zastosowaną w powyższym cytacie zasadę kształcenia/kształtowania człowieka za pośrednictwem języka. We wcześniejszym fragmencie Humboldt pisze o niej tak: ,język podziela i wspomaga najgłębszą istotę myślenia, którą jest ustawiczne wzajemne przechodzenie w siebie podmiotu i przedmiotu"27. Przy założeniu ekwiwalencji mówienia i myślenia stwierdzenie to naprowadza na sprzężenie zwrotne (Wechselwirkung), które przedstawił Schleiermacher we wspomnianych już Mowach o religii W obrazie miłosnego uścisku ${ }^{28}$. W tym kontekście należy podkreślić, że język interesuje Schleiermachera przede wszystkim ze względu na dążenie do prawdy. To z kolei wiąże się ze zdobywaniem wiedzy. O relacji między tą ostatnią a językiem mówił nasz autor w Projektach jednego systemu nauki moralności (Entwürfe zu einem System der Sittenlehre): „Bez języka [...] nie byłoby wiedzy, a bez wiedzy nie istniałby język" ${ }^{29}$. Wyjaśnienie tego problemu należy do podstawowych zadań Dialektyki (Dialektik), dzieła znacznie mniej znanego i docenianego w dorobku filozoficznym Schleiermachera niż Hermeneutyka i krytyka (Hermeneutik und Kritik) ${ }^{30}$.

We wstępie do wykładów z dialektyki z 1822 roku, które zrekonstruował Ludwig Jonas, uczeń Schleiermachera i zarządzający pośmiertnie jego spuścizną piśmienniczą, znajduje się następująca definicja tej dziedziny wiedzy: „Dialektyka jest przedstawieniem głównych zasad zgodnego z wymogami sztuki prowadzenia rozmowy w obszarze czystego myślenia" ${ }^{31}$. Wbrew pozorom autorowi nie chodzi o czyste myślenie i jego zasady w rozumieniu filozofii transcendentalnej, lecz wprost przeciwnie - przedmiotem jego zainteresowania jest doświadczenie jako jedyne źródło wiedzy. Schleiermacher stara się wyjaśnić, czym owo czyste myślenie jest, przeciwstawiając je „myśleniu interesownemu” i „myśleniu estetycznemu” ${ }^{32}$. Według niego,

${ }^{26}$ W. Humboldt, dz. cyt., s. 419.

${ }^{27}$ Tamże, s. 404.

${ }^{28}$ Por. F. Schleiermacher, Mowy o religii do wyksztatconych spośród tych, którzy niq gardza, Kraków 1995, s. 85 i nast.

${ }^{29}$ Cyt. za: F. Brüggen, Freiheit, s. 107.

${ }^{30}$ Por. M. Potępa, dz. cyt., s. 5-13.

${ }^{31}$ F. Schleiermacher, Dialektik, s. 5.

${ }^{32}$ Tamże. 
pierwszy rodzaj myślenia jest skierowany na osiaganie „celów zewnętrznych"33, drugi natomiast przypomina Kantowską władzę sądzenia estetycznego, w której rozstrzygnięcia zapadają na podstawie wewnętrznego kryterium upodobania lub nieupodobania. W czystym myśleniu jest zupełnie inaczej; jego celem jest bowiem ono samo, a dokładniej: jego pełnia albo doskonałość. Tym samym czyste myślenie można realizować wyłącznie „ze względu na samą wiedzę" ${ }^{34}$, ale ,nie w tym sensie, jakoby wiedza była czymś odmiennym [od myślenia], lecz dlatego, że każde czyste myślenie pragnie stać się wiedzą" ${ }^{35}$ i przez to zyskać status „niezmienności i ogólności” ${ }^{36}$. Mimo to, albo lepiej właśnie dlatego jego punktem zaczepienia jest praxis, której godność (Dignität) wynika z bycia transcendentalno-empirycznym warunkiem poznania i działania ${ }^{37}$. Czysta wiedza przypomina w znacznym stopniu mądrość życiową, którą przecież zdobywa się z refleksywnego nastawienia do samego siebie. Tak samo jak ona, „czyste myślenie [...], zanim osiagnie postać wyodrębnionego jestestwa, istnieje w każdej pojedynczej [istocie] jako to, co jest już dane w jej własnym myśleniu oraz w myśleniu innych [istot]" ${ }^{38}$. Nie będąc zatem niczym wyłącznie „,własnym i wyodrębnionym samo dla siebie" 39 , myślenie to czeka na ujawnienie wiedzy, która się w nim zawiera, za pomoca języka. Według Schleiermachera, prowadzi to do powstania mowy lub komunikatu, który jest równocześnie produktem myślenia jednostki i ogólnego użycia języka. Wiedza w nim zawarta przechodzi przez coraz wyższe poziomy, zmierzając do osiagnięcia „najwyższego dobra” (das höchste Gut). Pod tym wyrażeniem kryje się koncepcja idealnej wspólnoty dóbr (będzie o tym mowa w trzecim punkcie), przypominająca Platońską ideę Dobra.

Jak wyraźnie zaznacza Schleiermacher, różnicy między myśleniem a językiem nie da się w żaden sposób zniwelować czy przezwyciężyć. Oznaczałoby to bowiem urzeczywistnienie się „pojęcia «totalnej» koherencji

33 Tamże, s. 6.

34 Tamże, s. 7.

35 Tamże.

${ }^{36} \mathrm{~W}$ tym kontekście warto wskazać na teorię działania komunikacyjnego Jürgena Habermasa. Podobnie jak Schleiermacher, zakłada on możliwość istnienia wiedzy niezależnej od podziału na wiedzę praktyczną, czyli służącą realizacji celów zewnętrznych, i teoretyczną, to znaczy nakierowaną na cele wewnętrzne. W przeciwieństwie jednak do omawianego autora według Habermasa do orzekania o prawdzie w zupełności wystarczająca jest analiza interakcji społecznych. Por. J. Habermas, Technika i nauka jako ,,ideologia”, w: J. Szacki (red.), Czy kryzys w socjologii?, Warszawa 1977, s. 342-395.

${ }^{37}$ Por. F. Schleiermacher, Mowy, s. 74-75.

${ }_{38}$ Tenże, Dialektik, s. 24.

39 Tamże, s. 26. 
(podkr. F. S.)" ${ }^{\prime 40}$. Byłby to stan, w którym to, co realne, i to, co idealne, bycie i myślenie, poznanie i mówienie, stałyby się nierozdzielną jednością. W takich warunkach jednak, zauważa nasz autor, straciłaby sens dialektyka jako sztuka prowadzenia rozmowy, a niekiedy nawet sporu o prawdę ujmowaną $\mathrm{z}$ różnych perspektyw. Ponieważ jednak conditio humana charakteryzuje się , «niezmiennością w [relacji] przeciwstawienia między świadomością a przedmiotem» (podkr. F. S.) ${ }^{\prime \prime 41}$, dlatego pojawia się potrzeba hermeneutyki, która uzupełnia dialektykę.

W Hermeneutyce i krytyce Schleiermacher definiuje hermeneutykę, ,jako sztukę rozumienia" ${ }^{42}$. Jej potrzeba wynika stąd, że „nierozumienie powstaje samo z siebie, rozumienia zaś trzeba [...] poszukiwać i pragnąć w każdym punkcie"³. Jeszcze wyraźniej widać to, gdy się przypomni zasygnalizowaną powyżej „niewymazywalną różnicę w myśleniu” ${ }^{4}$. Jej piętno pozostaje zarówno w monologu wewnętrznym prowadzonym przez pojedynczego człowieka (Schleiermacher powiedziałby Eigentümlichkeit), jak i w komunikacji międzyludzkiej. W tym kontekście słuszna wydaje się uwaga Brüggena: „Cel rozmowy, [to znaczy] osiagnięcie «tożsamości wiedzy» i porozumienia, powoduje, że niezbędne staje się [postępujące] quasi w odwrotnym kierunku [wobec dialektyki] rozumienie tego, co różne, co jednak nie wydarza się przypadkowo, lecz wynika samo przez się z podstaw konstytuujących podmiot" ${ }^{\prime 4}$. Hermeneutyka jest rodzajem namysłu, w którym wbrew pokusie „tożsamości wiedzy” próbuje się ustalić ogólne zasady rozumienia tego, co indywidualne. Jak się to dokonuje?

Zdaniem Schleiermachera w interpretacji hermeneutycznej nakładaja się na siebie dwa sposoby wyjaśniania: gramatyczny i psychologiczny. Kryterium umożliwiającym ich rozróżnienie jest to, że każda mowa (język jako parole) opiera się na „podwójnej relacji”" ${ }^{\text {" }}$. Z jednej strony wiąże się z „,całokształtem języka" ${ }^{47}$, należałoby dodać: ujmowanego jako langue, z drugiej natomiast z „całym myśleniem jej twórcy”48. Dzięki temu „każde rozumienie składa się z dwóch momentów: rozumienia [indywidualnej] mowy jako

40 Tamże, s. 63.

41 Tamże, s. 62.

42 Tenże, Hermeneutik und Kritik, oprac. M. Frank, Frankfurt a.M. 1977, s. 75.

${ }^{43}$ Tamże, s. 92. Według Gadamera w hermeneutyce Schleiermachera dominuje psychologizm. Przeciw takiemu poglądowi wystąpi m.in. Frank. Por. M. Frank, dz. cyt., s. 20 i nast. oraz s. 46 i nast.

${ }^{44}$ F. Schleiermacher, Dialektik, s. 15.

${ }^{45}$ F. Brüggen, Freiheit, s. 111.

${ }^{46}$ F. Schleiermacher, Hermeneutik, s. 77.

47 Tamże, s. 78.

48 Tamże. 
tego, co zostało wydobyte z [ogólnego] języka, oraz z rozumienia tej samej mowy jako faktu [dokonującego się] w myślącym"49. Należy zauważyć, że Schleiermacher faktem (Tatsache) nazywa tutaj spontaniczną aktywność językową podmiotu, w której wykracza on zarówno poza dotychczasową tradycję, jak i obowiązująca konwencję. Widać w tym ślad nabudowanej na religii teorii kształcenia Schleiermachera ${ }^{50}$. Charakterystyczna dla niej współzależność - teraz można by doprecyzować: dialogiczno-dialektyczna - między (bierną) receptywnością a (aktywną) spontanicznością funkcjonuje w strukturze myślenia hermeneutycznego (wkrótce jeszcze do tego wrócę).

Pierwszy z wyróżnionych przez Schleiermachera momentów rozumienia - „całokształt języka” - odnosi się do gramatyki. Jednak wbrew pozorom w tym pojęciu nie zawierają się semantyczne i syntaktyczne reguły konstruowania wypowiedzi w języku czy to mówionym, czy pisanym, lecz to, co powoduje, że ,pojedynczą wypowiedź (Rede) da się zrozumieć tylko w kontekście całego życia [mówiącego]"51. Innymi słowy: Schleiermacherowi chodzi tutaj o wskazanie i wydobycie „całokształtu otoczenia" ${ }^{2}$, na który składają się zarówno poszczególne „momenty życiowe”53, jak i „,krag językowy" 54 , w ramach którego dana wypowiedź musi być interpretowana. Można zatem wyciagnąć wniosek, że gramatyka, tak jak ją ukazuje Schleiermacher, doprowadza do tego, że ,człowiek razem ze swoją aktywnością znika i pojawia się tylko jako organ języka"55. To zatracanie się indywidualności w tym, co ogólne, jest jednak tylko jednym z dwóch obrazów języka.

Przeciwieństwem przedstawionej powyżej anihilacji podmiotowości jest moment psychologiczny. Zgodnie z nim, stwierdza Schleiermacher, język przekształca się w „,organ człowieka”, ${ }^{56}$, czyli: „Język znika wraz ze swoją siłą określającą i pojawia się [...] w służbie indywidualności"57. Tak jak poprzednio „osobowość znajdowała się w służbie języka" ${ }^{58}$, tak teraz role się odwracają: język służy osobowości do doskonalenia się. W tym najpełniej przejawia się ,innowacyjna siła języka"59, przez którą podmiot tworzy coś nowego i kształtuje samego siebie.

49 Tamże.

${ }^{50}$ Por. D. Stępkowski, Czy religia jest do kształcenia koniecznie potrzebna? W 240. Rocznice urodzin Friedricha Schleiermachera, „Paedagogia Christiana” 22 (2008), s. 14-25.

${ }^{51}$ F. Schleiermacher, Hermeneutik, s. 78.

52 Tamże.

53 Tamże.

${ }^{54}$ Tenże, Dialektik, s. 13.

55 Tenże, Hermeneutik, s. 171.

56 Tamże.

57 Tamże.

58 Tamże.

${ }^{59}$ F. Brüggen, Freiheit, s. 112. 
Jeśli chodzi o koncepcję psychologiczną, to Schleiermacher skupia w niej uwagę na autorze wypowiedzi, dociekając, ,na czym polega jego praca w języku" ${ }^{\prime 60}$. Na podstawie własnych obserwacji wyciaga wniosek, że mówiący „,wytwarza częściowo coś nowego, ponieważ każde nieistniejące jeszcze połączenie podmiotu [wypowiedzi] z predykatem jest czymś nowym, a częściowo zachowuje to, co zastał gotowe, powtarza i przekazuje dalej”"61. Jakie więc jest przesłanie dla kształcenia?

Nieco wcześniej powiedziałem, że myślenie i język nie tworzą u Schleiermachera „totalnej koherencji”. Wprost przeciwnie - ich związek charakteryzuje się permanentną nieciagłością. Wskutek tego powstaje między nimijak to plastycznie opisuje Brüggen - ,perforacja" ${ }^{62}$. Dzięki niej dialektyczny ruch języka nie kończy się na samym sobie, lecz odnosi myślenie do „transcendentnej podstawy", która nadaje mu sens i treść. To przezwyciężenie ram językowych, którego dokonuje podmiot, Schleiermacher nazywa „wolnym czynem" ${ }^{63}$ i uznaje je za najważniejszą wartość „sztuki rozumienia” (hermeneutyki). Godne podkreślenia jest przy tym również to, że każda wypowiedź, jako wytwór „wewnętrznego myślenia” ${ }^{64}$, odsyła nie tylko do źródła sensu, lecz także jest skierowana na intersubiektywną „,wspólnotę języka" ${ }^{65}$. Między jednym a drugim panuje zależność, o której Schleiermacher mówi: „Każda indywidualna wypowiedź zakłada język dany z góry. Można to jednak odwrócić [...]: język staje się przez mówienie" $"$.

Nie dość jasno, jak mi się wydaje, został ukazany do tej pory innowacyjny charakter stawania się (kształcenia) indywidualności w języku i przez niego. Zanalizuję tę kwestię w odniesieniu do czynności tworzenia wypowiedzi i ich rozumienia. Według Schleiermachera, język spełnia przy tym dwie funkcje: „organiczną” i ,intelektualną”, nazwaną również „symboliczną". W pierwszej wyraża się związek każdej wypowiedzi z zastaną strukturą języka. Przez nią dokonuje się wszczepienie podmiotu w podmiotowoprzedmiotowe otoczenie, w którym żyje. Zadaniem funkcji intelektualnej

${ }^{60}$ F. Schleiermacher, Hermeneutik, s. 167.

${ }^{61}$ Tamże.

${ }^{62}$ F. Brüggen, Freiheit, s. 88.

${ }^{63}$ F. Schleiermacher, Hermeneutik, s. 182.

${ }^{64}$ Tamże, s. 78.

${ }^{65}$ Tamże.

${ }^{66}$ Tamże, s. 77-78. Mamy tu do czynienia z kołem hermeneutycznym. Zdaniem Brüggena rozumie się je w niewłaściwy sposób, jeżeli się sądzi, że chodzi w nim o „zasadniczą wtórność świadomości wobec bycia” (F. Brüggen, Freiheit, s. 113), albo inaczej: „wyższość obiektywnych sił duchowych nad indywidualnymi" (tamże). Jego zdaniem koło, o którym pisze Schleiermacher w Hermeneutyce i krytyce, jest „konsekwencją jego teorii podmiotu” (tamże) i wyraża niedający się zredukować związek momentu indywidualnego i społecznego, psychologicznego i gramatycznego języka. 
jest symbolizowanie, czyli wyrażanie własnych myśli. Schleiermacher podkreśla wzajemne powiązanie obu tych aktywności, to znaczy każda zakłada drugą jako swój warunek. Tylko dzięki temu możliwe jest tworzenie nowych wypowiedzi, a przez to nieustanny rozwój języka. Niemniej jednak nie pomniejsza to znaczenia każdej z tych funkcji z osobna. Dzięki funkcji organicznej powstaje „ogólny obraz”67 lub „postać ogólna”68 języka, w intelektualnej natomiast „pojęcie" ${ }^{69}$. „Miejscem systemu wszystkich postaci ogólnych czy obrazów” "70 jest „sens" "71, tak jak „miejsce systemu wszystkich pojęć i sądów" ${ }^{72}$ znajduje się w ,rozumie"73. Współdziałanie obu warunkuje tworzenie się tego, co nowe. W „przychylności organicznej”74 - jak inaczej jeszcze nazywa Schleiermacher wszczepianie za pomocą języka - to, co indywidualne, łączy się w jednej i tej samej czynności intelektu z tym, co ogólne. Wskutek tego język jest w stanie wyrażać różnorodne i zmienne stany rzeczy za pomocą danych uprzednio form ogólnych. Nasz autor mówi o tym następująco: „rzeczywiste ustanowienie tego, co szczegółowe jako czegoś określonego i «wkształcanie» (Hineinbildung) postaci ogólnej w sens, które [to «wkształcanie»] odpowiada określonemu miejscu w systemie pojęć, jest jednym i tym samym momentem (podkr. F. S.)"75. Na podstawie zacytowanego fragmentu można zdefiniować istotę języka: jest on ,znajdującą się w zawieszeniu jednością tego, co ogólne i tego, co szczegółowe"76. Jak stwierdza Brüggen, ze względu na dynamiczność tej struktury autor wypowiedzi musi mieć „,szczególną zdolność" 77 . Polega ona na tym, że „będąc w danym języku, znajduje się on zawsze ponad nim"78. Tej zdolności Schleiermacher nadał miano „dywinacji” ${ }^{\text {" }}$. Mimo że integralnie należy ona do jego teorii języka, poświęcam jej osobny podrozdział. Robię to głównie z tego powodu, że dywinacja, moim zdaniem, najlepiej wyjaśnia obecne w kontekście rozważań pedagogicznych Schleiermachera pojęcie ukształcalności (Bildsamkeit).

\footnotetext{
${ }^{67}$ F Schleiermacher, Dialektik, s. 356.

${ }^{68}$ Tamże.

${ }^{69}$ Tamże.

${ }^{70}$ Tamże, s. 358.

${ }^{71}$ Tamże.

${ }^{72}$ Tamże.

${ }^{73}$ Tamże.

${ }^{74}$ Tamże.

${ }^{75}$ Tamże, s. 357.

76 Tamże, s. 342.

${ }^{77}$ F. Brüggen, Freiheit, s. 116.

${ }^{78}$ Tamże.

${ }^{79}$ F. Schleiermacher, Hermeneutik, s. 325.
} 


\section{Dywinacja jako przejaw ukształcalności ${ }^{80}$}

Aby wyjaśnić znacznie terminu «dywinacja» (Divination), można odwołać się do jego źródłosłowu, którym jest łaciński czasownik divinare, oznaczający przepowiadanie, prorokowanie, przeczuwanie. Utworzony od niego rzeczownik divinatio ma jednak dwa sensy, a mianowicie: (1) dar proroczy, przeczucie i (2) wyznaczenie oskarżyciela. W tym drugim obecne są konotacje terminu «dywinacja» związane z obiektywizmem. Oskarżycielem bowiem może być tylko ktoś, kto równie dobrze jak sprawca, chociaż nie z autopsji, zna sprawę. Przenosząc to na grunt analiz hermeneutycznych Schleiermachera, w których nie chodzi o sprawcę i oskarżyciela, lecz autora wypowiedzi i interpretatora, dywinacja gwarantuje prawdziwość poglądu, zgodnie z którym „wyjaśnienie osiaga najwyższą doskonałość, gdy rozumie się autora lepiej, niż on sam byłby do tego zdolny"81. Aby przekonać do słuszności tego stwierdzenia, konieczne jest przybliżenie sensu dywinacji.

Przedmiotem rozważań we fragmencie Hermeneutyki i krytyki, w którym pojawia się termin «dywinacja», jest interpretacja tekstu poetyckiego. Przez dywinację Schleiermacher określa aktywność interpretatora, który dąży do zrekonstruowania niepowtarzalnej „,swoistości” ${ }^{82}$ wypowiedzi twórcy. „Nie ma tutaj żadnej innej możliwości postępowania, jak tylko, wychodząc dywinacyjnie (divinatorisch) od stanu, w którym znajdował się autor przy tworzeniu [swoich] myśli, odkryć, dlaczego potrzeba chwili mogła tak, a nie inaczej wpłynąć na posiadany przez niego zasób języka"83. Wyjaśniając ten fragment, Brüggen zauważa, że Schleiermacherowi „nie chodzi o odosobniony akt wczucia się w cudzą indywidualność przy jednoczesnym abstrahowaniu od jakichkolwiek porównań z obowiązującymi w danym czasie ogólnymi zasadami językowymi" ", lecz wprost przeciwnie - dywinacja zakłada przeprowadzenie najpierw postępowania komparatywnego. „Oba [typy postępowania: dywinacja i porównanie] odwołują się do siebie nawzajem, gdyż pierwsze z nich opiera się na tym, że każdy człowiek, mimo że jest kimś wyjątkowym, posiada wrażliwość wobec innych. Wydaje się,

${ }^{80}$ Por. D. Stępkowski, Uksztatcalność jako zasada działania edukacyjnego. W sprawie zapomnianej kategorii Herbarta i jej wspótczesnej reinterpretacji, w: M. Kowalski, A. Pawlak, A. Jamuła-Jurczak (red.), Przestrzeń edukacyjna - dylematy, doświadczenia i oczekiwania społeczne, Kraków 2010, s. 37-58.

${ }^{81}$ F. Schleiermacher, Hermeneutik, s. 325.

82 Tamże, s. 172.

${ }^{83}$ Tamże, s. 325.

${ }^{84}$ F. Brüggen, Freiheit, s. 117. 
że pochodzi to stąd, że każdy nosi w sobie pewne minimum [łączące go] z wszystkimi innymi. Wskutek tego porównania z samym sobą pobudzona zostaje dywinacja" ${ }^{\prime 5}$.

W jaki jednak sposób może dojść do dywinacji w podmiocie, któremu brakuje jeszcze doświadczeń zdobytych w trakcie działania komparatywnego? Gdyby była ona ściśle uzależniona od tego ostatniego, byłoby to niemożliwe. To sugeruje, że kolejność wskazanych rodzajów aktywności podmiotowej może ulegać zmianie. W niektórych sytuacjach dywinacja poprzedza porównywanie. Chociaż, jak podkreśla Schleiermacher, „dywinacja zdobywa swoją pewność dopiero dzięki potwierdzającemu porównaniu. Bez tego byłaby ona czymś fantastycznym. Natomiast [działanie] komparatywne nie gwarantuje żadnej jedności. To, co ogólne i co indywidualne muszą wzajemnie się przenikać, to zaś dokonuje się zawsze tylko przez dywinację"

Można byłoby się zastanawiać, co to ma wspólnego z wychowaniem i pedagogiką. Aby dostrzec istniejący tutaj związek, trzeba uświadomić sobie, że porozumienie - umożliwione przez dywinację - między „twórczym aktem" ${ }^{87}$ autora a odpowiadającą mu re-produkcją ze strony interpretatora dotyczy każdej formy komunikowania, również tego, które zachodzi między wychowawcą a wychowankiem czy pokoleniem dorastających a dorosłymi, jak to zostanie poniżej przedstawione. Można więc stwierdzić, że wartość Schleiermacherowskiej koncepcji dywinacji nie wynika jedynie z ukazania warunków powstawania porozumienia między podmiotami interakcji, lecz także z wyjaśnienia tworzenia czegoś nowego. Tutaj kryje się jej potencjał innowacyjny. Jak dzięki dywinacji powstaje „nowe”, wyjaśnię, odwołując się do przykładu dziecka uczącego się mówić, który Schleiermacher zaprezentował w Hermeneutyce i krytyce.

Jak wynika z dotychczasowych rozważań, dywinacja nie ma nic wspólnego $\mathrm{z}$ tajemniczym wczuwaniem się $\mathrm{w}$ innego, lecz jest strukturalnym momentem każdej komunikacji. Do jej zaistnienia wymagana jest pewna cecha, którą Brüggen nazywa „odwagą dywinatorską" ${ }^{88}$. Polega ona na mężnym przechodzeniu od nierozumienia do rozumienia i vice versa. Schleiermacher wskazuje na nia, pytając, w jaki sposób „dzieci zaczynają rozumieć to, co się do nich mówi" $"$. W odpowiedzi nasz autor stwierdza:

\footnotetext{
${ }^{85}$ F. Schleiermacher, Hermeneutik, s. 169.

${ }^{86}$ Tamże, s. 170.

${ }^{87}$ Tamże, s. 325.

${ }^{88}$ F. Brüggen, Freiheit, s. 119.

${ }^{89}$ F. Schleiermacher, Hermeneutik, s. 326.
} 
Języka jeszcze nie posiadają, dopiero go szukają, ale także nie znają jeszcze czynności myślenia, gdyż nie ma myślenia bez słów: od której strony więc rozpoczną [uczenie się]? Nie mają jeszcze żadnych punktów umożliwiających porównanie i dopiero stopniowo je zdobywają jako podstawę dla nieoczekiwanie szybko postępującego działania komparatywnego. Jak zatem utrwalają to, co pierwsze? Czy nie należy ulec pokusie powiedzenia, że każdy [z tychże punktów] produkuje w sposób pierwotny oba i albo uzgadnia się to na podstawie wewnętrznej konieczności z tym, jak inni [ja] wytworzyli, albo stopniowo się do tego zbliża w miarę, jak opanowuje on działanie komparatywne? Ale również to - wewnętrzna aktywność [skłaniająca] do własnego wytwarzania - jest tylko tym samym, co określiliśmy za pomocą wyrażenia dywinacji. Tak więc jest ona tym, co pierwotne ${ }^{90}$.

Schleiermacher podkreśla ,prawie nieskończoną siłę tworzenia”", jaka tkwi w dziecku, które w produktywno-reproduktywnym procesie przyswaja sobie język i stopniowo wchodzi w krag używanej mowy. Każde dziecko wytwarza „oba elementy w pierwotny sposób od początku”"92, to znaczy to, co ogólne i to, co szczegółowe dla każdego języka. Dopiero potem wyodrębniają się one jako coś osobnego: moment gramatyczny i moment psychologiczny. Tak więc uczenie się nie polega na przyswajaniu czegoś już z góry gotowego (np. przez instruowanie), lecz na opanowywaniu tego przez działanie interaktywne, jak można by to wyrazić współczesnym językiem. Ma zatem rację Schleiermacher, twierdząc, że „dzieci pierwotnie są wynalazcami'"93. Nie należy jednak sądzić, że dokonuje się w nich ,absolutne uczenie się"94, czyli takie, które powstaje niejako ex nihilo. Sprawę tę wyjaśnia Brüggen, nawiązując do Platońskich fascynacji Schleiermachera: „Dla thumacza Platońskiego Menona uczenie się oznacza przyswajające przekształcenie czegoś już uprzednio znanego. [...] Dzieci są dla Schleiermachera «pierwotnymi wynalazcami» dlatego, że w procesie zakotwiczonego w praktyce życiowej przyswajania języka powstają «oba momenty»: ogólność językowa i to, co ma być za każdym razem ujęte pojęciowo"95.

Kończąc te rozważania, należy podkreślić, że, według Schleiermachera, język jest „konieczną funkcją człowieka"96. Daje mu on bowiem możliwość „wykroczenia poza siebie samego [i przejścia] do wspólnotowości (Gemein-

\footnotetext{
${ }^{90}$ Tamże, s. 326-327.

${ }^{91}$ Tamże, s. 327.

92 Tamże, s. 170.

${ }_{93}$ Tamże, s. 367.

${ }^{94}$ Tamże.

${ }^{95}$ F. Brüggen, Freiheit, s. 120.

${ }^{96}$ F. Schleiermacher, Hermeneutik, s. 367.
} 
schaftlichkeit)"97. Pytania: w jaki sposób to się dokonuje i jak człowiek współtworzy ową wspólnotowość, stanowią wstęp do następnego punktu.

\section{Wyznaczenie przestrzeni dialogu międzypokoleniowego}

Dość obszerne rozważania na temat teorii języka Schleiermachera miały na celu przygotowanie fundamentu do szerszego przedstawienia tego, jak powstaje sfera międzypodmiotowa, i wydobycia jej roli w myśleniu o wychowaniu. Za pośrednictwem języka tworzy się wspólna przestrzeń, która nie ogranicza się do dziedziny komunikacji. Jest ona także płaszczyzną wolności i dążenia do dobra najwyższego. Oba te terminy, choć różnią się od siebie, mają ze sobą wiele wspólnego. W ich świetle widać bowiem wyraźnie, że teoria języka jest wprowadzeniem do refleksji etycznej, której zadaniem jest doprecyzowanie zasygnalizowanej problematyki związku między indywidualnością a wspólnotowością.

W powyższych wywodach na temat dywinacji padło słowo Hineinbildung, którego użył Schleiermacher dla przedstawienia aktu włączenia tego, co pojedyncze i określone, w całokształt sensu. Na język polski przełożyłem ten termin jako „wkształcanie”, chcąc w nim zachować odniesienie do dziedziny pedagogiki, o którą tutaj chodzi. Hineinbildung zawiera bowiem w temacie rzeczownik Bildung oznaczający kształcenie/kształtowanie. Prefiks hinein wskazuje na ruch do wnętrza, do środka. Tłumacząc dosłownie, Hineinbildung oznacza wkształcanie/wkształtowywanie, czyli osadzanie kogoś/ czegoś za pomocą kształcenia w większej całości. Jednak dosłowne translacje rzadko się sprawdzaja, dlatego chciałbym wykorzystać jedynie sens zawarty w Hineinbildung jako klucz do zrozumienia problemu podjętego przez Schleiermachera zarówno w Zarysie sztuki wychowania (Grundzüge der Erziehungskunst), jak i Etyce (Ethik). Jest nim, moim zdaniem, kwestia włączenia „osobności”, którą jest każdy człowiek sam w sobie, w ramy poprzedzającej go i warunkującej ogólności.

Myślą przewodnią opracowania Brüggena Freiheit und Intersubjektivität, które towarzyszy moim analizom, jest charakterystyczna dla Schleiermachera figura argumentacyjna, jaką jest relacja hypolepsis - antycypacja. Pierwszy z terminów brzegowych pochodzi z Etyki nikomachejskiej Arystotelesa i oznacza konieczność wyrażającą się w znanym również z dydaktyki postulacie: ,zaczynać trzeba od rzeczy znanych” (1095 b). W pedagogicznych tekstach Schleiermachera hypolepsis odpowiada rozważana nieustannie kwestia Anknüpfen, czyli punktu wyjścia lub zaczepienia w refleksji na

97 Tamże. 
temat wychowania. Brüggen przekonująco wykazał, że u protestanckiego teologa i pedagoga analiza stanu wyjściowego wskazuje zarazem kierunek dla dalszych poszukiwań. To oznacza właśnie antycypacja, tworząca z hypolepsis nierozdzielny związek, ,prawdziwie dialektyczną jedność”98.

Z tym samym mamy również do czynienia w Schleiermacherowskiej Etyce. Jej autorowi nie chodzi właściwie o subtelne rozróżnienia między koncepcjami etyki jako „nauki o dobrach” (Güterlehre), ,nauki o obowiązkach” (Pflichtenlehre) czy „nauki o cnocie” (Tugendlehre), lecz o wydobycie myśli lub idei, która je ze sobą wiąże. W innym opracowaniu, a mianowicie w powstałych w latach 1802-1803 Gtównych liniach krytyki dotychczasowej nauki moralności (Grundlinien einer Kritik der bisherigen Sittenlehre), Schleiermacher kończy przegląd najważniejszych starożytnych i nowożytnych doktryn moralnych konkluzją: „nigdzie jeszcze nie dostrzeżono, że oba [elementy] - to, co ogólne i to, co szczegółowe - jednoczą się ze sobą według jednej idei" ${ }^{99}$. Tą ideą jest dla niego dobro najwyższe ${ }^{100}$. Aby ją przybliżyć, konieczne jest przynajmniej skrótowe przedstawienie struktury wspomnianych powyżej Głównych linii krytyki... Kurt Nowak, współczesny biograf Schleiermachera, zauważa w kontekście tej monografii, że jest ona „najmniej lubiana, choć niezwykle ważna”101, gdyż „stanowi zwieńczenie jego studiów etycznych, które przeprowadził do tego czasu"102.

Po prześledzeniu założeń systemów etycznych od Platona i Arystotelesa przez stoików do Kanta i Fichtego, Schleiermacher dochodzi do wniosku, że wszystkie są niepełne (fragmentaryczne). Zarówno antycznym, jak i nowożytnym koncepcjom brakuje bowiem zrozumienia dla ruchu oscylacyjnego między „czynem” (Tat) a jego obiektywacją w postaci „dzieła” (Werk $)^{103}$. Pierwszy człon tego stosunku - czyn - wiąże refleksję etyczną z wolą. Potwierdzeniem tego są definicje przedmiotu etyki, które ujmują go od strony

${ }^{98}$ F. Brüggen, Freiheit, s. 47.

${ }^{99}$ Cyt. za: F. Brüggen, Freiheit, s. 146.

${ }^{100}$ Dwie prace na temat dobra najwyższego spinają w całość jakby jedną klamrą życie i dzieło Schleiermachera. Pierwsza z nich to młodzieńczy esej powstały w 1789 roku podczas studiów na uniwersytecie w Halle pt. $O$ dobru najwyższym (Über das höchste Gut), który w ostatnim czasie został przypomniany przez Brüggena (por. F. Brüggen, Freiheit, s. 51-63). Druga praca to złożony z dwóch części referat pt. O pojęciu dobra najwyższego (Über den Begriff des höchsten Gutes). Pierwsza część powstała w 1827 roku, druga zaś trzy lata później - 1830. Obie zostały zaprezentowane przez autora na posiedzeniach Pruskiej Akademii Nauk.

${ }^{101}$ K. Nowak, Schleiermacher. Leben, Werk und Wirkung, Göttingen 2002, s. 127.

${ }^{102}$ Tamże, s. 129.

${ }^{103}$ F. Schleiermacher, Grundlinien einer Kritik der bisherigen Sittenlehre, w: tenże, Kritische Gesamtausgabe, cz. I, t. 4: Schriften aus der Stolper Zeit (1802-1804), oprac. E. Herms, G. Meckenstock, M. Pietsch, Berlin-New York 2002, s. 167. 
obowiązku lub cnoty. Drugi człon - dzieło - włącza do tak zakreślonego obszaru kwestię dobra. Mimo to etyka nie wyczerpuje się w tych trzech podejściach. Każdy przejawiający się w przedmiotowym dziele akt ma swoją „godność praktyczną"104. Jej źródłem nie jest jednak żadna ze składowych czynu moralnego, lecz omówiona w pierwszym punkcie „godność praxis”. $\mathrm{Z}$ jej powodu nie da się zredukować działania ani do samego tylko wytworu (pragmatyka), ani spełniania określonych czynności (technika). Nawiązując do użytego przez Brüggena terminu ,perforacja”, można by powiedzieć, że według Schleiermachera w ludzkim działaniu prześwieca zawsze jakieś „więcej”. Etyka ma zajmować się doprecyzowaniem, czym to „więcej” jest. $\mathrm{Z}$ tych rozważań można wyciagnać co najmniej jeden wniosek: etyka jest wszechobecna. Innymi słowy, każde działanie (czy to polityczne, czy ekonomiczne, czy religijne) musi dokonywać się w sposób odpowiedni dla człowieka, czyli moralny.

Niewatpliwie Schleiermacher przez wydobycie moralnego fundamentu ludzkiego działania dokonał rozszerzenia pojęcia praxis, które w każdym z wymienionych trzech podejść było zawężone. Ten zabieg niesie ze sobą ważne konsekwencje. Jedną z nich jest zdezaktualizowanie się starożytnych kategorii poiesis (wytwarzanie) i praxis (działanie), dla których ogólną ramą było życie w polis, czyli polityka ${ }^{105}$. Aby odkryć sens ludzkiego działania - to wniosek, który wysnuł stąd Schleiermacher - trzeba całą uwagę skoncentrować na nim samym, to znaczy działaniu, a nie uwarunkowaniach wewnętrznych czy zewnętrznych. Występując przeciwko Arystotelesowi, pisał on: „Patrząc na sposób, w jaki łączy on etykę z nauką o państwie, [...] wszelkie działanie może być tylko działaniem obywatelskim"106. Przez to „potrafił on odnaleźć wartość etyczną [...] tylko w ruchu działania” ${ }^{107}$, nie zaś „w spoczywającym namyśle” 108 . Ale bez tego ostatniego niemożliwe jest przenikanie wszystkiego - w tym również etyki - przez religię, jak to wyraził Schleiermacher w słynnej maksymie: „wszystko z towarzyszeniem religii, nic $[\ldots]$ z powodu religii”"109.

Dla moich dalszych analiz konieczne jest dookreślenie, jaki nowy sens Schleiermacher nadaje praxis. W nierozerwalny sposób wiąże się to z kwestią dobra najwyższego. Zamierzam ją wyjaśnić na podstawie wspomnianego powyżej dwuczęściowego traktatu pt. O pojęciu dobra najwyższego.

\footnotetext{
${ }^{104}$ F. Brüggen, Freiheit, s. 144.

${ }^{105}$ Por. tamże, s. 144 i nast.

${ }^{106}$ F. Schleiermacher, Grundlinien, s. 43.

107 Tamże.

108 Tamże.

${ }^{109}$ Tenże, Mowy, s. 83.
} 
W jego drugiej części Schleiermacher rekonstruuje strukturę praxis. Jego zdaniem, składają się na nią dwie płaszczyzny. Pierwszą z nich tworzą dwie przeciwstawne aktywności. Zgodnie z wypracowaną przez siebie nomenklatura, nasz autor oznacza je odpowiednio przydawkami: «organizująca» (organisierende) $\mathrm{i}$ «symbolizująca» (symbolisierende). Specyficzny sens każdej z nich wynika ze źródła, z którego pochodzą. Aktywność organizująca jest domeną „,natury” (Natur), którą w człowieku reprezentuje sfera cielesno-zmysłowa, natomiast aktywność symbolizująca odnosi się do „rozumu” (Vernunft). Ludzkie działanie wynika zawsze ze zjednoczenia (Einigung) obu tych aktywności ${ }^{110}$.

Jednak na tym charakterystyka praxis się nie wyczerpuje. Istnieje bowiem druga płaszczyzna, którą wyznacza również para przeciwstawnych określeń. Tym razem są nimi znane już z teorii języka terminy: to, co własne i osobne (das Eigentümliche), i to, co identyczne (das Identische). To ostatnie wyrażenie jest ekwiwalentne z omówionym powyżej zwrotem „to, co ogólne" (das Allgemeine). Żeby się nie powtarzać, przypomnę tylko, że Schleiermacher za ich pomocą opisywał „podwójność” (Duplizität) języka $\mathrm{z}$ jednej strony jako własności jednostki, z drugiej zaś jako wytworu wspólnoty językowej.

Z kontaminacji obu płaszczyzn powstaje struktura, którą, zdaniem Brüggena, należy odczytywać jako Schleiermacherowskie pojęcie dobra ${ }^{111}$. Po przyjęciu tego wskazania staje się jasne, że dobro w teorii Schleiermachera nie może być ujmowane ani jako rzecz materialna, ani jakaś wartość duchowa, która by istniała sama w sobie i dla siebie ${ }^{112}$. Dobro jest możliwe jedynie $\mathrm{w}$ praxis i rzeczywiście powstaje w niej jako skrzyżowanie obu wskazanych płaszczyzn działania.

Tak zdefiniowana praxis obejmuje wszystkie dziedziny ludzkiego działania i stanowi ich wspólny mianownik. Jako przykłady Schleiermacher podaje działalność ekonomiczną (handel), naukową, artystyczną i polityczną ${ }^{113}$. Warto podkreślić, że wskutek tego obowiązujące do tej pory polityczne wyznaczniki podziału praxis zastapiło nowe kryterium - ,pożytek ekonomiczny" 114 . Błędem byłoby sądzić, że autor sugeruje potrzebę, by poddawać

${ }^{110}$ Tenże, Über den Begriff des höchsten Gutes. Zweite Abhandlung, w: tenże, Kritische Gesamtausgabe, cz. I, t. 11: Akademievorträge, red. M. Rössler, Berlin-New York 2002, s. 665 i nast.

${ }^{111}$ Por. F. Brüggen, Freiheit, s. 147.

${ }^{112}$ Teorie i koncepcje, które nie pobudzają człowieka do aktywności, porównuje Schleiermacher do „wyeksploatowanej kopalni lub zupełnie wyjałowionego i dlatego opuszczonego pola, które przestają być dobrem”. F. Schleiermacher, Über den Begriff, cz. I, s. 545.

${ }^{113}$ Por. tamże, s. 547.

${ }^{114}$ Tamże, s. 545. 
wycenie różnorodne typy ludzkiej aktywności ze względu na ich wartość ekonomiczna. Chodzi mu raczej o podkreślenie „,inteligentnej produkcji” ${ }^{115}$, jaka dokonuje się za każdym razem w praxis i przez nią ${ }^{116}$. W omawianym referacie Schleiermacher pisze o tym następująco: „Dobra [...] są zawsze czymś, co wynika z ludzkiej aktywności, ale jednocześnie ta ostatnia włącza je w siebie i rozkrzewia dalej" ${ }^{117}$. Czym wobec tego jest dobro najwyższe?

Wyjaśnienie tej sprawy jest najważniejszym zadaniem, jakie postawił sobie Schleiermacher w pierwszej części omawianego traktatu. Wśród licznych zwrotów wyrażających istotę dobra najwyższego najczęściej powtarza się sformułowanie: „całokształt wszystkich dóbr”118. Termin „dobro”, który w nim występuje, trzeba interpretować zgodnie z wyżej przedstawionym jego znaczeniem. Na tym tle łatwiej zrozumieć stwierdzenie Schleiermachera, że dobro najwyższe jest pewną ,konstrukcją" ${ }^{119}$. W celu jej scharakteryzowania wyróżnię w niej dwa momenty: po pierwsze, przedmiotowy, czyli to, co jest konstruowane, i po drugie, metodologiczny, to znaczy, w jaki sposób się to dokonuje.

Odnośnie do pierwszego momentu na początku drugiej części referatu Schleiermacher zwraca uwagę na niebezpieczeństwo błędnego odczytania słowa «całokształt» (Gesamtheit). Stwierdza on: „w sposób zupełny dobro najwyższe może być oglądane tylko w całokształcie «rodzaju ludzkiego» (podkr. D.S)” ${ }^{120}$, nie zaś w „całokształcie istot rozumnych”"121. Wydawać by się mogło, że różnica między tym wyrażeniami jest niewielka. W pierwszym przypadku punktem odniesienia jest ludzkość jako jedność scalająca wszystkie pokolenia, które zaistniały już w historii lub dopiero się pojawią, w drugim natomiast akcent pada na pojedynczą istotę rozumną, która z innymi podobnymi do siebie „inteligencjami” (Inteligenzen) może również tworzyć jakąś wspólność (Gesamtheit). Niemniej jednak, według naszego autora, „prawdziwym i właściwym miejscem” ${ }^{122}$ przejawiania się dobra najwyższego jest „wspólnota pierwotna"123, czyli ta składająca się nie z jednostek, lecz pokoleń.

${ }^{115}$ Tamże, s. 547.

${ }^{116} \mathrm{~W}$ tym kontekście Brüggen uzasadnia, że w teorii Schleiermachera należy doszukiwać się początków nowożytnej koncepcji niehierarchiczności praxis. Por. F. Brüggen, Freiheit, s. 163 i nast.

${ }^{117}$ F. Schleiermacher, Über den Begriff, cz. I, s. 545.

${ }^{118}$ Tamże, s. 544; zob. także s. 546, s. 548; tenże, Über den Begriff, cz. II, s. 661, 662,668 .

${ }^{119}$ Tenże, Über den Begriff, cz. I, s. 544.

${ }^{120}$ Tenże, Über den Begriff, cz. II, s. 660.

121 Tamże, s. 667.

${ }^{122}$ Tamże, s. 660.

${ }^{123}$ Tamże, s. 667. 
Element spajający poszczególne pokolenia zawarty jest w praxis, a jest nim wytwarzane w niej dobro. Predykat „najwyższe” przysługuje owemu dobru dlatego, że scalają się w nim „,czyny, które już się dokonały i te, które się [aktualnie] dokonują"124. Tę specyficzną jedność dobra najwyższego, w której współistnieją równocześnie przeszłość i teraźniejszość, Schleiermacher opatruje terminem Gesamttätigkeit. Przekładając go na język polski, trzeba by użyć wyrażenia „całokształt aktywności”. Ważne w nim są dwa elementy, na które chciałbym zwrócić uwagę. Po pierwsze, dobro najwyższe jest ściśle związane z praxis, to znaczy powstaje jako jej produkt $\mathrm{i}$ istnieje razem z nią. Cechą nadającą mu specyficznego charakteru jest przy tym to, że źródłem praxis nie jest pojedynczy podmiot działający, lecz wszystkie pokolenia ludzkości. To jest ów drugi element, który, moim zdaniem, należy podkreślić w Gesamttätigkeit. Dla uzupełnienia dodam, że indywidualna praxis określonego człowieka stanowi część (partycypuje w) ponadpodmiotowej Gesamttätigkeit dzięki znamionującej ją etyczności, o której była mowa powyżej. Można zatem powiedzieć, że z jednej strony dobro najwyższe tworzy doskonałą pełnię ,wszystkich dóbr prawdziwych”" ${ }^{25}$, z drugiej natomiast pozostaje otwarte na dopełnienie przez ,inteligentną produkcję pojedynczego" 126 człowieka. Ta pozornie sprzeczna konstatacja prowadzi do drugiego momentu, który chciałbym wskazać w konstrukcji dobra najwyższego. Powyżej oznaczyłem go jako metodologiczny, gdyż w omawianym traktacie Schleiermacher wyjaśnia również sposób „wspinania się [...] do coraz doskonalszej postaci” ${ }^{127}$ dobra najwyższego.

Mimo że podstawowym założeniem każdej aktywności ludzkiej jest, zdaniem Schleiermachera, istnienie idealnej jedności wszystkich dóbr - dobra najwyższego, to jednak niedwuznacznie wskazuje on na to, że zachodzi proces jego „stawania się (Werden)" ${ }^{128}$. Aby znaleźć do tego uzasadnienie, należy wskazać na proces , uduchowienia (Vergeistigung)" "129, który zachodzi między naturą a rozumem, aktywnością organizującą a symbolizująca, świadomością a byciem. Krystalizująca się przez to jedność jest czymś więcej niż tylko sumą elementów składowych ${ }^{130}$. Jak powstaje owo „więcej”?

Schleiermacher rozważa ten problem w odniesieniu do wskazanego wyżej podmiotu dobra najwyższego - pokolenia (Generation). Jego zdaniem, wejście w jego posiadanie nie dokonuje się bezwiednie, lecz wymaga świa-

\footnotetext{
${ }^{124}$ Tenże, Über den Begriff, cz. I, s. 550.

125 Tamże, s. 546.

126 Tamże, s. 547.

${ }^{127}$ Tamże, s. 551.

${ }^{128}$ Tenże, Über den Begriff, cz. II, s. 664.

${ }^{129}$ Tenże, Über den Begriff, cz. I, s. 551.

${ }^{130}$ Por. tamże, s. 540 i nast.
} 
domego podjęcia określonych działań. Każde pokolenie musi „,najpierw rozwinaćc swoją inteligencję na podstawie tej [wypracowanej przez] poprzednie generacje, następnie stać się aktywne w wyznaczonych sobie ramach i w końcu przekazać swoją aktywność za pomocą działań inspirujących znajdującej się jeszcze w trakcie rozwoju następnej generacji" ${ }^{131}$. Za pośrednictwem tego mechanizmu dokonuje się nie tylko modyfikacja dobra najwyższego, lecz także ciągle się poprawia „stan ogólny ludzkich spraw”"132, osiągając coraz wyższe szczeble rozwoju. Zanim przejdę do następnego punktu, w którym scharakteryzuję rolę oddziaływania pedagogicznego w procesie kształtowania dobra najwyższego, zatrzymam się jeszcze krótko nad wyodrębnionymi przez Schleiermachera obszarami Gesamttätigkeit.

Jak mi się wydaje, główną przesłanką skłaniającą do wyszczególnienia czterech form w jednorodnej przestrzeni ,całokształtu aktywności” pokoleniowej było przekonanie, że, świadomość rozwija się zawsze tylko we wspólnocie pojedynczych istot"133. Po rozpatrzeniu praxis zgodnie z zasadą,,pożytku ekonomicznego" Schleiermacher wskazał następujące ,wielkie wspólnoty etyczne"134: państwo (Staat), towarzyskość (Geselligkeit), naukę (Wissenschaft) i religię (Religion). W tych czterech obszarach realizuje się dialog między dorosłymi a dorastającymi, któremu poświęcam następny podrozdział.

\section{Pedagogika jako „technika” dialogu między pokoleniami}

Zabieg zakotwiczenia (wkształcenia przez praxis) indywidualnej „samoaktywności” (Selbsttätigkeit) w „całokształcie aktywności” (Gesamttätigkeit) rodzaju ludzkiego, którego punktem kulminacyjnym jest statyczno-dynamiczna idea dobra najwyższego, prowadzi - zdawać by się mogło - do rozmycia, a nawet anihilacji „osobowości” (Persönlichkeit). Nie dziwi więc, że w oczach wielu interpretatorów koncepcja filozoficzna Schleiermachera uchodziła za romantyczną utopię. Tym bardziej że potwierdzały to niektóre jego wypowiedzi, jak np.: „Wszystko stało się jednym obyczajem”135. Przystępując do charakterystyki Schleiermacherowskiej teorii wychowania, rozpocznę od dokładniejszej analizy tego problemu.

Na zakończenie pierwszego z dwóch omawianych w poprzednim punkcie referatów O pojęciu dobra najwyższego nasz autor dokonuje kluczowego

${ }^{131}$ Tenże, Über den Begriff, cz. II, s. 661.

${ }^{132}$ Tamże, s. 666.

${ }^{133}$ Tamże, s. 672.

${ }^{134}$ Tenże, Grundzüge der Erziehungskunst (Vorlesungen 1826), w: tenże, Texte zur Pädagogik, t. 2, oprac. M. Winkler, J. Brachmann, Frankfurt a.M. 2000, s. 50.

${ }^{135}$ Tamże, s. 64. 
w tej kwestii rozróżnienia. Jego zdaniem, do zjednoczenia tego, co różnorodne, może dojść na dwa sposoby. Jedność, która powstaje w każdym z nich, oznaczają odpowiednio terminy: Einerlei i Eigentümlichkeit. Pierwszy z nich to po polsku ,jednakowość". Schleiermacher przedstawia jego sens na przykładach zaczerpniętych $\mathrm{z}$ dyskursu filozoficznego i teologicznego. Jego zdaniem, ideę dobra najwyższego jako jednakowości prezentuje obraz złotego wieku (Fichte), koncepcja wiecznego pokoju (Kant), postulowana w filozofii tożsamości „pełnia i niezmienność wiedzy we wspólnocie języka” ${ }^{136}$ czy wreszcie program „królestwa niebieskiego w wolnej wspólnocie pobożnej wiary"137, który poznał podczas pobytu w herrenhuckiej gminie religijnej ${ }^{138}$.

Drugi z powyższych terminów - Eigentümlichkeit - oddaje własne stanowisko Schleiermachera. Mimo odniesienia do jedności, idea ta różni się zasadniczo od koncepcji jednakowości. Aby w pełni ukazać różnice między nimi, trzeba by od początku prześledzić dotychczasowe rozważania. Wskażę jedynie, że na Eigentümlichkeit skupiała się cała moja uwaga. Termin ten thumaczyłem dotychczas jako „osobność"139. Mam nadzieję, że udało mi się wykazać, że Schleiermacher, stosując to pojęcie, wyraża „zasadę uduchowienia” 140 czy też „duchową ukształcalność” 141 , jakie charakteryzują byt ludzki - samoaktywność. Dodatkowym potwierdzeniem jest użyty w Zarysie sztuki wychowania zwrot persönliche Eigentümlichkeit ${ }^{142}$, czyli w dosłownym przekładzie „osobowa osobność”.

Pod koniec drugiej części tego samego referatu, to znaczy $O$ pojęciu dobra najwyższego, Schleiermacher wraca do tematu odmienności swojego podejścia wyrażonego w Eigentümlichkeit wobec jednakowości. Zawiera się to właściwie w jednym, typowym dla języka niemieckiego, zdaniu złożonym. Warto je zacytować i zanalizować.

${ }^{136}$ Tenże, Über den Begriff, cz. I, s. 552.

137 Tamże.

${ }^{138}$ Por. D. Stępkowski, Czy religia, s. 10 i nast.

${ }^{139}$ Znamienne jest, że Mieczysław A. Krąpiec, przystępując do wyjaśniania terminu „osoba ludzka”, rozpoczyna od etymologicznego sensu polskiego słowa „osoba”. Za Aleksandrem Brücknerem podaje, że: Słowianin urobił od zwrotu «o sobie» (samym) przysłówek «osob» - «osobnie» [...] podobnie łac. «persona» («per se» tj. «dla siebie»” (cyt. za: M. A. Krąpiec, Człowiek jako osoba, Lublin. 2005, s. 113). Wydaje mi się, że na tle tej interpretacji można głębiej zrozumieć istotę Schleiermacherowskiego Eigentümlichkeit, które zawiera w swoim temacie przysłówek eigen posiadający znaczenia zbliżone do słowiańskiego „osob”, a mianowicie „własny”, „swój”, „osobny”, „właściwy”, „,swoisty”, „osobliwy”, „,szczególny” (J. Piprek, J. Ippoldt, Wielki słownik niemiecko-polski, t. 1, Warszawa 2001, s. 466).

${ }^{140}$ F. Schleiermacher, Grundlinien, s. 551.

${ }^{141}$ Tenże, Grundzüge, s. 38.

${ }^{142}$ Tamże, s. 38-39. 
Schleiermacher pisze:

W czasowo powstającej samoświadomości bezpośredniej pojedyncza istota duchowa ustanawia samą siebie jako przyjmującą do swojej osobności (vereigentümlichend) to, co ogólne, albo uogólniająca (verallgemeinend) to, co indywidualne, podczas gdy poszczególna dusza realizuje się w każdym momencie wyłącznie jako rozum, a będąc zajęta czynnością symbolizująca, [tworzy siebie] równocześnie jako jedność bycia i świadomości, albo nosi w sobie to, co absolutnie proste, to znaczy «odciska się» (prägt sich aus) jako samoświadomość etyczna i pobożna (podkr. D.S.) ${ }^{143}$.

Świadomie nie podzieliłem tego (zbyt) długiego zdania na mniejsze okresy, aby przedstawić próbkę stylu pisarskiego Schleiermachera. Na marginesie można zauważyć, że jego teksty przez swoją potoczystość i wielowątkowość przypominają styl mówiony, ale równocześnie są niezwykle skomplikowane $\mathrm{z}$ powodu stosowanej w nich terminologii.

Jeśli chodzi o powyższy fragment, skoncentruję się wyłącznie na wyróżnionym kursywą czasowniku „odciskać się”. Wydaje mi się bowiem, że zawiera on klucz do zrozumienia sensu „osobności”.

Najpierw zwrócę uwagę na podmiot spełniający wskazaną w nim czynność. Ku niemałemu zdziwieniu tych, którzy może by sądzili, że chodzi tu o wyciskanie piętna na samoświadomości bezpośredniej (tak Schleiermacher określa pojedynczego człowieka) przez którąś z wymienionych powyżej „wielkich wspólnot etycznych” (państwo, towarzyskość, nauka, religia), bliższa analiza wskazuje coś wręcz przeciwnego: to jednostka jest źródłem aktywności i ona właśnie „odciska się” w nich. Jak to wyjaśnić?

Pomocą w tym jest wspomniana już nowa zasada podziału obszarów praxis, którą Schleiermacher nazywa ,pożytkiem ekonomicznym”. To dość niejasne sformułowanie staje się bardziej zrozumiałe w kontekście krótkiego wywodu poprzedzającego dywersyfikację praxis na przed chwilą wymienione cztery zakresy „wspólnotowości”. Odtworzę go w skrócie.

Ponieważ praxis polega na wytwarzaniu dóbr - od tych najprostszych do dobra najwyższego - to podmiot, działając, pozyskuje te dobra (Erwerbung). Stanowią one jego własność (Besitz), którą może wprowadzić w obieg (Verkehr) dokonujący się w ramach „wspólnotowości procesu kształcenia"144. Zasady rządzące wymianą reguluje prawo. Nad jego stanem (Rechtzustand) czuwają wymienione cztery wielkie formy społeczne. To, co poszczególna „osobność” wprowadza do obiegu, zależy wyłącznie od niej samej. Problem,

${ }^{143}$ Tenże, Über den Begriff, cz. II, s. 674.

${ }^{144}$ Tamże, s. 668. 
z którym za każdym razem musi się ona zmierzyć, Schleiermacher wyraża w typowy dla siebie sposób za pomocą przeciwstawienia: „posiadaniewspólnota" ${ }^{145}$, to znaczy: ile mam zachować dla siebie, a ile mogę udostępnić wspólnocie.

$\mathrm{Na}$ pierwszy rzut oka trudno w tym wywodzie dopatrzeć się związku z analizowaną kwestią nieprzechodniego odciskania się „osobności” w „całokształcie aktywności” rodzaju ludzkiego. Gdy jednak spojrzy się na ten problem z uwzględnieniem właśnie naszkicowanego - można powiedzieć i powstałego dzięki praxis rynku wymiany dóbr, to wówczas okazuje się, że „osobność” jest podmiotem dla dwóch rodzajów aktywności. W bezpośredniej świadomości jest ona przedrefleksyjną jednością myślenia i działania, a przez uczestnictwo w obrocie dobrami jest częścią zbiorowości. To właśnie zmusza ją do wchodzenia w relacje z innymi.

Ostatnia myśl naprowadza na główny problem Zarysów sztuki wychowania - dialog intergeneracyjny. Zanim zajmę się przedstawieniem tego zagadnienia, postaram się w skrócie wyjaśnić specyfikę języka pedagogicznego Schleiermachera.

W przyjętej przez wielkiego teologia i pedagoga terminologii wychowanie jest „sztuką” (Kunst), pedagogika natomiast „techniką” (Technik), innymi słowy - teorią oddziaływania pedagogicznego (pädagogische Einwirkung). Terminów «sztuka» $\mathrm{i}$ «technika» nie należy zbyt pochopnie odczytywać w sensie antycznych poiesis i techne ani ich współczesnego zunifikowania $\mathrm{w}$ formie technologii ${ }^{146}$. Żeby zrozumieć tę nomenklaturę, konieczne jest przypomnienie ,godności praxis”, która oznacza uprzedniość działania (praxis) wobec teorii. Do tego właśnie nawiązuje Schleiermacher, gdy rozpoczyna swoje główne dzieło pedagogiczne od stwierdzenia: „Co w ogólności rozumie się przez wychowanie, należy założyć jako znane"147. Z tego lakonicznego, mimo to niezwykle ważnego zdania, wynika niedwuznacznie, że warunkiem koniecznym zarówno oddziaływania pedagogicznego (sztuki wychowania), jak i teorii na jego temat (pedagogiki) jest istnienie określonych czynności oznaczanych jako wychowanie. Aby je spełniać, namysł teoretyczny wcale nie jest konieczny. Przynosi jednak korzyść, gdy wychowanie staje się „,coraz więcej sztuką"148, czyli jest refleksyjnie prześwietlane.

Podsumowując te wywody, należy podkreślić, że relacja między wychowaniem (=sztuka) a pedagogiką (=technika właściwa dla tej sztuki) cechuje się dialektycznym napięciem. Wynika ono z jednej strony ze sprzężenia

\footnotetext{
145 Tamże, s. 669.

${ }^{146}$ Por. F. Brüggen, Freiheit, s. 121 i nast.

${ }^{147}$ F. Schleiermacher, Grundzüge, s. 7.

148 Tamże, s. 9.
} 
zwrotnego, w którym wskazane wielkości brzegowe - sztuka i technika warunkują siebie nawzajem, z drugiej natomiast praxis pozostaje poza ich wpływem jako podmiotowa samoaktywność (Selbsttätigkeit) zakorzeniająca jednostkę w „całokształcie aktywności” ogólnoludzkiej. W tym kontekście Schleiermacher twierdzi, że: „Godność praxis jest niezależna od teorii; [ale] dzięki tej ostatniej praxis staje się bardziej świadoma"149. Warto więc zapytać: czym jest praxis pedagogiczna?

W poprzednim podrozdziale wykazałem, że według Schleiermachera właściwym podmiotem praxis nie jest pojedynczy człowiek, lecz rodzaj ludzki jako całość. Jako, ,pierwotna wspólnota” bezpośrednio wiąże się z pełnią, którą jest dla niego dobro najwyższe. Oprócz tego statycznego elementu drugim znamieniem podmiotu zbiorowego jest „doskonalenie się” (Vervollkommnung). Źródłową rolę odgrywa przy tym zmiana między pokoleniami. Jej mechanizm Schleiermacher opisuje następująco:

Rodzaj ludzki składa się z pojedynczych istot, które przechodzą pewien cykl na ziemi i z niej potem znikają. Dokonuje się to w ten sposób, że wszystkich należących jednocześnie do określonego cyklu można podzielić na generację starszą i młodszą, z których pierwsza wcześniej opuszcza ziemię. Dopiero wówczas, gdy rodzaj ludzki rozpatrujemy w większych skupiskach, nazywanych narodami, widzimy, że w trakcie zmiany pokolenia nie pozostają ciagle takie same, ale powoduje w nich ona pewne «wznoszenie się» i «opadanie», do czego przykładamy tutaj szczególną wagę. [Kwestię:] Czy dokonuje się to tak, iż - spoglądając na całokształt życia danego narodu - owo wznoszenie się tworzy jedną jego połowę, opadanie zaś drugą, czy też oba procesy występują naprzemian, pozostawmy tutaj nierozstrzygniętą. Jasne jest wszakże, że u podstaw owego wznoszenia się i opadania leży ludzka aktywność. Jest ona tym doskonalsza, im lepsze poprzedza ją wyobrażenie o tym, co powinno się dokonać, i [lepszy] model określa, jak należy to zorganizować, to znaczy: im bardziej przekształca się ona w sztukę. Duża część czynności starszego pokolenia ma za odbiorcę młode pokolenie; są one tym bardziej niedoskonałe, im mniej wiadomo, co się robi i dlaczego to się robi ${ }^{150}$.

Po tych rozważaniach pada pytanie, na które odpowiedzią jest właściwie cała pedagogika Schleiermachera. Brzmi ono: „«Czego właściwie chce pokolenie dorosłych od młodej generacji?»[podkr. D. S.]"151. Zdaniem Brüggena sformułowanie tego pytania wyznacza moment narodzin pedago-

\footnotetext{
149 Tamże, s. 11.

${ }^{150}$ amże, s. 9.

151 Tamże.
} 
giki intergeneracyjnej152. Inni badacze zgłaszają jednak swoje wątpliwości odnośnie do tej tezy ${ }^{153}$. Pozostawiając na boku tę kontrowersję, skupię się na samym pytaniu. Od niego Schleiermacher rozpoczyna budowę zrębów swojej teorii pedagogicznej.

W przeciwieństwie do Arystotelesa, który chyba jako pierwszy pisał o wychowaniu w paradygmacie relacji dorośli-dorastający, adresatami rozważań Schleiermachera są osoby dorosłe, jednak nie w znaczeniu jednostek (rodzice) czy pewnych grup zawodowych (guwernerzy, nauczyciele szkół publicznych), lecz jako pokolenie. „Historyczną nowością jest tutaj to, że pokolenie wychowujące postrzegane jest całościowo jako podmiot odpowiedzialny za wychowanie. W epokach poprzedzających nowożytność starsze pokolenie w ogóle nie istniało jako uniwersalny podmiot odpowiedzialności pedagogicznej" 154 . W tym świetle relacja dorośli-dorastający przestaje zależeć od polityki, jak to było obowiązującą normą od czasów Arystotelesa, i przechodzi w sferę wewnętrznych odniesien między pokoleniami. Czy jednak istnieje taka wspólna płaszczyzna, gdy dobro państwa straciło prawomocność?

Rozważając tę kwestię, Schleiermacher wskazuje w Zarysie sztuki wychowania płaszczyznę spraw dotyczących bezpośrednio dorosłych i dorastających, oznaczając ją niemieckim rzeczownikiem Mitgesamttätigkeit ${ }^{155}$. Niewatpliwie wymaga on rozszyfrowania.

Rozpocznę od obserwacji etymologicznej. Schleiermacher utworzył pojęcie Mitgesamttätigkeit od omawianego już terminu Gesamttätigkeit, dodając do niego prefiks „mit”. Ten ostatni ze względu na swoją pierwotną funkcję jest przyimkiem i oznacza po polsku 'z', 'razem', 'wspólnie', 'pospołu'. $\mathrm{W}$ złożeniach - jak to ma miejsce w tym przypadku - przez ów przyimek zaznacza się równoczesność czasu i miejsca lub współsprawstwo w pewnym działaniu. Zakotwiczając więc sens Mitgesamttätigkeit w Gesamttätigkeit, należałoby je przetłumaczyć jako 'współdziałanie w całokształcie aktywności’ pokolenia dorosłych. Jeśli się przypomni, że najważniejszym celem Gesamttätigkeit było „,prezentowanie dobra najwyższego" $156 \mathrm{w}$ indywidual-

${ }^{152}$ Por. F. Brüggen, Die Entdeckung des Generationenverhältnisses - Schleiermacher im Kontext, ,Neue Sammlung“ 3 (1998), s. 265-279.

${ }^{153}$ Por. M. Winkler, Friedrich Schleiermacher revisited. Gelegentliche Gedanken über Generationenverhältnisse in pädagogischer Hinsicht, w: J. Ecarius (red.), Was will die jüngere mit der älteren Generation? Generationenbeziehungen und Generationenverhältnisse in der Erziehungswissenschaft, Opladen 1997, s. 115-138.

${ }^{154}$ F. Brüggen, Die Entdeckung, s. 274.

${ }^{155}$ F. Schleiermacher, Grundzüge, s. 16.

${ }^{156}$ Tenże, Über den Begriff, cz. II, s., s. 672. 
nych „manifestacjach"157, czyli etycznej praxis jednostek, to przez dodanie przedrostka „mit” Schleiermacher rozszerza zakres jego obowiązywania na pokolenie dorastających. Trzeba im umożliwić partycypację w realizacji „ogólnego zadania etycznego" ${ }^{158}$, którym jest podniesienie ludzkości na wyższy poziom.

Z powyższego jasno wynika, że pedagogika Schleiermachera ściśle współgra z etyką. Potwierdzają to jego własne słowa: „Pedagogika jest związaną wyłącznie z etyka, nauką stosowana, z niej wprowadzoną i skoordynowaną z polityką"159. Na czym polega jej zależność od etyki, mam nadzieję, rozjaśni się w toku dalszych moich rozważań.

Innym argumentem potwierdzającym tezę o etycznym fundamencie teorii pedagogicznej Schleiermachera jest to, że przedmiotem oddziaływania pedagogicznego nie jest jego zdaniem poznanie (Erkennen) i wiedza (Wissen), lecz Gesinnung ${ }^{160}$.I znowu mamy do czynienia z terminem, którego nie da się jednoznacznie przenieść na język polski. W niemczyźnie oznacza on 'usposobienie', 'charakter', 'sposób myślenia', 'przekonanie'. Moim zdaniem pełny sens, jaki przypisał temu pojęciu Schleiermacher, widać w zdaniu: „Pedagogika zasadza się na wglądzie w etyczność”161. Innymi słowy: przez wychowanie młode pokolenie powinno nie tylko teoretycznie zaznajomić się z tym, czym jest etyczna praxis, lecz przede wszystkim w pewien sposób samemu tego doświadczyć. Tylko dzięki temu ukształtuje się w nim etyczny sposób myślenia (Gesinnung).

Jednak nie w tym manifestuje się novum podejścia Schleiermachera. Kształtowanie postaw i wyrabianie cnót moralnych od zawsze należy do zadań stawianych wychowaniu. Jednak dotychczasowe myślenie o tej sprawie popada, zdaniem Schleiermachera, w circulus vitiosus. Nasz autor wywodzi: „Moglibyśmy sądzić, że na pytanie: Co oddziaływanie [pedagogiczne] «powinno» powodować?, [prawidłowa] odpowiedzią jest [twierdzenie]: Etyczność następnej generacji. Na pytanie zaś: Co przez nią [tj. etyczność nowego pokolenia] «może» być dokonane - to samo (podkr. D.S.)"162, czyli etyczność kolejnej generacji. Takie podejście zasługuje na krytykę z co najmniej trzech powodów: po pierwsze, punktem wyjścia jest w nim założenie, że etyczność jest czymś niezmiennym i doskonałym, po drugie, wychowanie moralne polega na transmisji wyobrażeń dotyczących dobra z jednego pokolenia na drugie bez potrzeby ich modyfikowania, i po trzecie, taki sposób

\footnotetext{
${ }^{157}$ Tamże, s. 674.

158 Tenże, Grundzüge, s. 12.

159 Tamże, s. 13.

160 Tamże, s. 31.

161 Tamże, s. 30.

162 Tamże, s. 14.
} 
postępowania uniemożliwia prawdziwe „zjednoczenie” (Einigung) między starszymi a dorastającymi, gdyż z góry pozbawia tych ostatnich prawa do głosu. Po uświadomieniu sobie tego warto wrócić do wyjściowego w Zarysie sztuki wychowania pytania: „Czego właściwie chce pokolenie dorosłych od młodej generacji?"”63. Teraz nabiera ono nowego sensu. Spróbuję go odczytać.

Warunkiem dialogu jest to, że każda ze stron może do niego wnieść własny wkład. Powyższe pytanie jest według mnie nie tyle wyrazem bezradności i dezorientacji dorosłych w kontaktach z dorastającymi, ile raczej wezwaniem skierowanym do dorosłych, aby zapytali siebie o oczekiwania, plany i nadzieje, jakie wiążą z dorastającymi. Takie pytanie nie zostanie postawione, dopóki ci pierwsi w ogóle nie zastanawiają się nad tym, co robią, to znaczy nad wychowaniem młodej generacji. Jak zaznaczyłem powyżej, źródłem pedagogiki jest według Schleiermachera praxis, a jej początkiem refleksja nad działaniem. W tym kontekście warto krótko nawiązać do terminów «sztuka» i «technika».

W ujęciu starożytnych sztuka była imitowaniem (gr. mimesis) rzeczywistości, któremu podporządkowywało się działanie wytwórcze (gr. techné). Nowożytność nie tylko zmieniła sens pojęć «sztuka» i «technika», ale również odwróciła ich stosunek wobec rzeczywistości. Za pomocą nowoczesnej techniki (technologii) powstają modele działania, które nie czerpią swoich prawideł z rzeczywistości, lecz wprost przeciwnie - koncypują je w oderwaniu od niej i jej narzucają (konstruktywizm). Zarówno jedno podejście, jak i drugie nie mają nic wspólnego ze Schleiermacherowskim określeniem wychowania jako sztuki i pedagogiki jako techniki. Należy na nie patrzeć z perspektywy rozważanej właśnie kwestii współdziałania ponad granicami pokoleń i wynikającego stąd problemu „modyfikowalności”164 lub „etycznego udoskonalania"165 relacji międzypokoleniowych.

Warto się zastanowić nad tym, z jaką reakcją może spotkać się zademonstrowana przez pytanie gotowość starszego pokolenia do dialogu z młodymi ze strony tych ostatnich? Dopóki podchodzi się do wychowania bezrefleksyjnie, proces socjalizacji młodej generacji może przebiegać dwiema drogami: albo zgodnie z zasadą „,naśladownictwa” ${ }^{166}$, to znaczy „młode pokolenie przedstawia zwierciadlane odbicie etycznej niedoskonałości starszych"167, albo według „formuły rewolucyjnej”. Z tym drugim podejściem mamy do

\footnotetext{
163 Tamże, s. 9.

164 Tamże, s. 35.

165 Tamże, s. 36.

166 Tamże, s. 58.

167 Tamże.
} 
czynienia wówczas, gdy ,nie dąży się do niczego innego jak tylko do wychowania młodzieży na reformatorów"168. W pierwszym przypadku wychowanie ,zatrzymało się na martwej literze”169, w drugim natomiast „ulepszanie wpływa destrukcyjnie, niszcząc dokonania przeszłości [...]. To właśnie określamy [w nim] wywrotowo-rewolucyjnym (das Revolutionäre)" "170.

Schleiermacher w typowy dla siebie sposób wskazuje drogę wyjścia przez scalenie obu opcji w dialektycznym związku: ,zachowanie i ulepszanie"171. Równocześnie jest to odpowiedź na wyjściowe pytanie o cele przyświecające dorosłym przy wychowaniu młodego pokolenia. Z całą pewnością nie jest to odpowiedź, jakiej by się spodziewano. Tak naprawdę jest to zadanie do wykonania - trzeba bowiem się zastanowić, co z dotychczasowych doświadczeń warte jest zachowania i co należy ulepszyć. Po rozważaniu tego można określić, jakie działania powinny zostać podjęte dla zrealizowania wyznaczonych celów ${ }^{172}$. To wykracza jednak poza zakres moich rozważań.

Ostatnią kwestią, którą się zajmę, jest określenie możliwości aktywnego udziału młodego pokolenia $\mathrm{w}$ dialogu $\mathrm{z}$ dorosłymi. Do tej pory dominowało bowiem spojrzenie z perspektywy starszej generacji. Na czym, zdaniem Schleiermachera, zasadza się możliwość Mitgesamttätikeit, czyli współdziałania młodzieży w całokształcie aktywności dorosłych? Czy nie jest to aby tylko jego pobożne życzenie?

Aby udzielić odpowiedzi na powyższe pytania, należy sięgnąć do przedstawionej powyżej teorii języka, w szczególności zaś do omówionej w drugim punkcie koncepcji dywinacji. Nie tylko zamyka to krag moich rozważań, ale również dowodzi, że dialogiczność relacji międzypokoleniowych w ujęciu Schleiermachera nie jest żadną przenośnią, lecz implikuje zwyczajne rozmawianie i ,sztukę prowadzenia rozmowy” - dialektykę.

Za punkt wyjścia przyjmę w tym rozważaniu fragment Zarysu sztuki wychowania, w którym Schleiermacher zastanawia się nad tym, czy w wychowaniu „wolno bieżącą chwilę poświęcać na rzecz przyszłej”"173. Odpowiedzi na tę kwestię udziela, odnosząc się do etycznego wymiaru praxis, w którym teraźniejszości i przyszłości nie można interpretować oddzielnie

\footnotetext{
${ }^{168}$ Tamże, s. 34.

${ }^{169}$ Tamże.

${ }^{170}$ Tamże.

${ }^{171}$ Tamże.

${ }^{172} \mathrm{~W}$,technologicznej” części wprowadzenia do Zarysu sztuki wychowania Schleiermacher rozpatruje czynności pedagogiczne w oparciu o inną konstrukcję dialektyczną, a mianowicie ,wspieranie-przeciwdziałanie”. Tamże, s. 57 i nast.

${ }^{173}$ Tamże, s. 51.
} 
ani żadnej z nich dyskredytować ${ }^{174}$. Ja jednak chcę rozważyć powyższy problem w nawiązaniu do pojęcia dywinacji. Wówczas jednak konieczne jest przeformułowanie wyjściowego pytania: czy dziecko (wychowanek), które nie jest jeszcze dojrzałe (mündig), może partycypować w Mitgesamttätikeit? Gdyby podchodzić do tego od strony dojrzałości czy to biologicznej, czy prawnej ${ }^{175}$, jest to niemożliwe. Dlatego Schleiermacher obiera inną drogę, a mianowicie poszukuje pedagogicznego sensu dojrzałości (Mündigkeit). Rezultat jego analizy można by streścić za Bennerem w wyrażeniu „dojrzałość pedagogiczna"176. Jest to stan, gdy wychowanek jest zdolny samodzielnie wykonywać określone działania. Osiagnięcie takiego stanu jest tożsame $\mathrm{z}$ wejściem do Gesamttätigkeit jako dojrzały (mündig) podmiot. Przejście dokonuje się zawsze przez Mitgesamttätigkeit. To wskazuje, że sfera dialogu wychowawczego nie odnosi się do okresu w życiu wychowanka tuż przed osiagnięciem pełnoletniości prawnej, lecz jest to charakterystyczna cecha pedagogicznej praxis. Jak to możliwe, że dziecko nieustannie przechodzi z niedojrzałości do dojrzałości, czyli się uczy?

W kontekście Schleiermacherowskiej teorii języka została przedstawiona koncepcja dywinacji. W związku z hermeneutycznym problemu rozumienia wyjaśnia ona, w jaki sposób interpretator jest w stanie odczytać myśl auto$\mathrm{ra}^{177}$. Gdyby przenieść ten schemat na grunt przedstawionej powyżej sytuacji uczenia się przez dziecko, oznaczałoby to, że jest ono owym interpretatorem, który ma za zadanie odczytać obcą mu rzeczywistość (to, co przedstawia się mu jako już zastany stan rzeczy). Brüggen przekonuje jednak, że rozumienie nigdy nie jest biernym przyswajaniem, lecz wskutek dywinacji (aktywnego rozumienia) jest zawsze również produktywne ${ }^{178}$. Tak więc w rozumieniu łączy się element reprodukcji i produkcji w jedność. Nie dokonuje się to jednak automatycznie. Stąd też ze strony wychowawcy konieczne jest skierowanie do wychowanka „zewnętrznego wezwania” ${ }^{179}$, przez które „wywabia (lockt hervor)" ${ }^{180}$ on z niego receptywno-spontaniczną, „samoaktywność".

Wracając do rozważań nad aktualnym momentem w wychowaniu, nie można się zgodzić z poglądem, że musi być on złożony w ofierze przyszłości. Wynika to stąd, że przez dywinację przyszłość jest już antycypowana.

${ }^{174}$ Por. tamże, s. 51-57.

${ }^{175}$ Por. tamże, s. 105.

${ }^{176}$ D. Benner, Wychowanie a przekaz tradycji. Główne problemy innowacyjnej teorii i praxis transmisji kultury, w: tenże, Edukacja jako kształcenie i kształtowanie. Moralność kultura - demokracja-religia, Warszawa 2008, s. 109.

${ }^{177}$ Zob. rozważania z drugiego punktu.

${ }^{178}$ Por. F. Brüggen, Freiheit, s. 157 i nast.

${ }^{179}$ F. Schleiermacher, Grundzüge, s. 61.

${ }^{180}$ Tamże, s. 51. 
Dialog między wychowawcą i wychowankiem rozpoczyna się od stanu obecnego (hypolepsis), ale już w punkcie wyjścia zawiera w sobie zarodki przyszłości.

Odnosząc to do związku między pokoleniem młodszym i starszym, należy podkreślić, że tematem ich komunikacji powinny być teraźniejszość i sprawy bieżące. W tym, co aktualne, jednoczy się bowiem przeszłość wnoszona przez starszych i przyszłość antycypowana przez młodszych.

\section{Zakończenie}

Błędem byłoby sądzić, że przedstawiona koncepcja Schleiermachera jest zamkniętym rozdziałem historii idei pedagogicznych, który być może warto poznać, ale nie ma on już większego znaczenia dla współczesnego myślenia o wychowaniu. Zaprzecza temu Dietrich Benner, który w Allgemeine Pädagogik nie dość, że przypomina zapomnianą, a w naszym kraju w ogóle nieznaną teorię, to ponadto stara się ją rozwijać. Kończąc swoje wywody, chciałbym z tego właśnie opracowania zacytować fragment, który, moim zdaniem, dopełnia ideę Mitgesamttätigkeit o problem, który - jak mi się wydaje - czyni ją atrakcyjną i wartą dogłębnego przestudiowania. Zdaniem współczesnego niemieckiego pedagoga, warunkiem rzeczywistego dialogu między pokoleniami jest powstanie i jakość społecznego klimatu, to znaczy: „czy społeczeństwo otworzy się na współdziałanie z dorastającymi i przejmie część odpowiedzialności za realizację pedagogicznej praxis w realnych sytuacjach życia"181. Innymi słowy: czy obie strony będą chciały znowu przebywać razem i się sobą ubogacać, czy też każda pójdzie swoją drogą?

\section{Schleiermachers Erziehungsdenken in Form Intergenerationellen Dialogs (Zusammenfassung)}

Den pädagogischen Schriften von Schleiermacher liegt dialektische Denkfigur zu Grunde, die an den bekannten aus der griechischen Antike Begriff des Dialogs (dia-logos) zurückzuführen ist. Seine Struktur wird dargestellt zum einen als Oszillation zwischen Sprache und Denken, zum anderen als Wechselbeziehung zwischen dem „transzendenten Grund“ und dem ,unmittelbaren Selbstbewusstsein“, oder anders gesagt: Wissen und Erkennen.

${ }^{181}$ D. Benner, Allgemeine Pädagogik, Weinheim und München 2010, s. 300. 
Der Verfasser des Artikels geht davon aus, dass das obige Reflexionsschema auch in Schleiermachers Denken über Erziehung Anwendung gefunden hat. In Bezug auf das in Polen gänzlich unbekannte pädagogische Hauptwerk des berühmtesten protestantischen Theologen des 19. Jahrhunderts Grundzüge der Erziehungskunst wird versucht, den in der Sprachtheorie angelegten dialogisch-dialektischen Ansatz herauszuheben und seine Relevanz für die Grundlegung der Pädagogik als „Technik“ des intergenerationellen Diskurses aufzuzeigen.

Der argumentative Leitfaden verläuft in vier Punktem. Zunächst wird die in bisheriger Rezeption des Schleiermachers Hermeneutik unterbeleuchtete Sprachtheorie hinsichtlich ihrer pädagogisch relevanten Aussagekraft skizzenhaft rekonstruiert. Im zweiten Punkt richtet sich das Augenmerk auf den Begriff der Divination, der bildungstheoretisch ausgedeutet wird. Danach geht man zum Grundriss ethischen Konzepts von Schleiermacher über, dessen Aufgabe ist, den Rahmen des Diskurses zwischen den Erwachsenen und den Nachwachsenden zu bestimmen. Abschließend wird das Novum der intergenerationalen Fragestellung in Schleiermachers Theorie pädagogischer Praxis erörtert. 